\title{
PROCESSES WHICH DISTRIBUTE SUPRAGLACIAL DEBRIS ON THE KHUMBU GLACIER, NEPAL HIMALAYA
}

\author{
by \\ M. Nakawo \\ (Department of Applied Physics, Faculty of Engineering, Hokkaido University, Sapporo 060, Japan) \\ and \\ S. Iwata
}

(Department of Geography, Tokyo Metropolitan University, Setagaya, Tokyo 158, Japan)

and

O. Watanabe and M. Yoshida

(Water Research Institute, Nagoya University, Nagoya 464, Japan)

\section{ABSTRACT}

The thickness of supraglacial debris on the Khumbu Glacier, Nepal Himalaya, has been mapped by a combination of direct measurements and morphological and lithological studies. All three processes, englacial, supraglacial, and subglacial, must be considered in establishing the distribution of debris. Taking advantage of the lithological characteristics of the debris and their bedrock source, the denudation rate of the schistose bedrock was estimated to be about $0.02 \mathrm{~mm} \mathrm{a}^{-1}$. A rough estimate of the production rate of supraglacial debris indicated that most of the present debris has formed since the last advance of the glacier, which took place a few hundred years B.P.

\section{INTRODUCTION}

Many glaciers in Nepal Himalaya are covered by debris in their ablation area. The rock fragments become visible below the equilibrium line and increase, in their layer thickness, gradually downglacier. The debris layer can be as thick as several tens of metres near the terminus of the glaciers.

The Khumbu Glacier, a typical debris-covered glacier, drains mainly the West Cwm between Mt. Sagarmatha (Mt. Qomolangma or Mt. Everest), Mt. Lhotse, and Mt. Nuptse. It flows down from about $6800 \mathrm{~m}$ to $4900 \mathrm{~m}$ in elevation, over a distance of more than $15 \mathrm{~km}$. The equilibrium line is located at an ice fall, just upstream from the Everest Base Camp (5300 a.s.1.). The ablation area is mostly covered by supraglacial debris, except for a limited area near the Everest Base Camp, and can be delineated by lateral and terminal moraines. From results of ${ }^{14} \mathrm{C}$ age dating, it was concluded that the moraines formed during the Little Ice Age (Fushimi, 1978).

Extensive investigations of supraglacial debris on the glacier were carried out during the 1978 monsoon season (Watanabe et al., 1980), because the debris is of great importance in studying glacier hydrology and dynamic changes of the glacier. The morphological and lithological characteristics of the debris have also been mapped previously (Iwata et al., 1980; Fushimi et al., 1980). In this paper, a contoured map of the debris thickness is presented and the formation of the mass of supraglacial debris is discussed, in terms of various processes responsible for its present distribution.
DEBRIS THICKNESS AND LITHOLOGICAL FEATURES

The thickness of supraglacial debris was determined by direct measurement at about 50 places, in areas on the glacier where the supraglacial debris was rather thin (Glaciological Expedition of Nepal, 1980). It was possible also to measure thickness, even in areas with thick debris

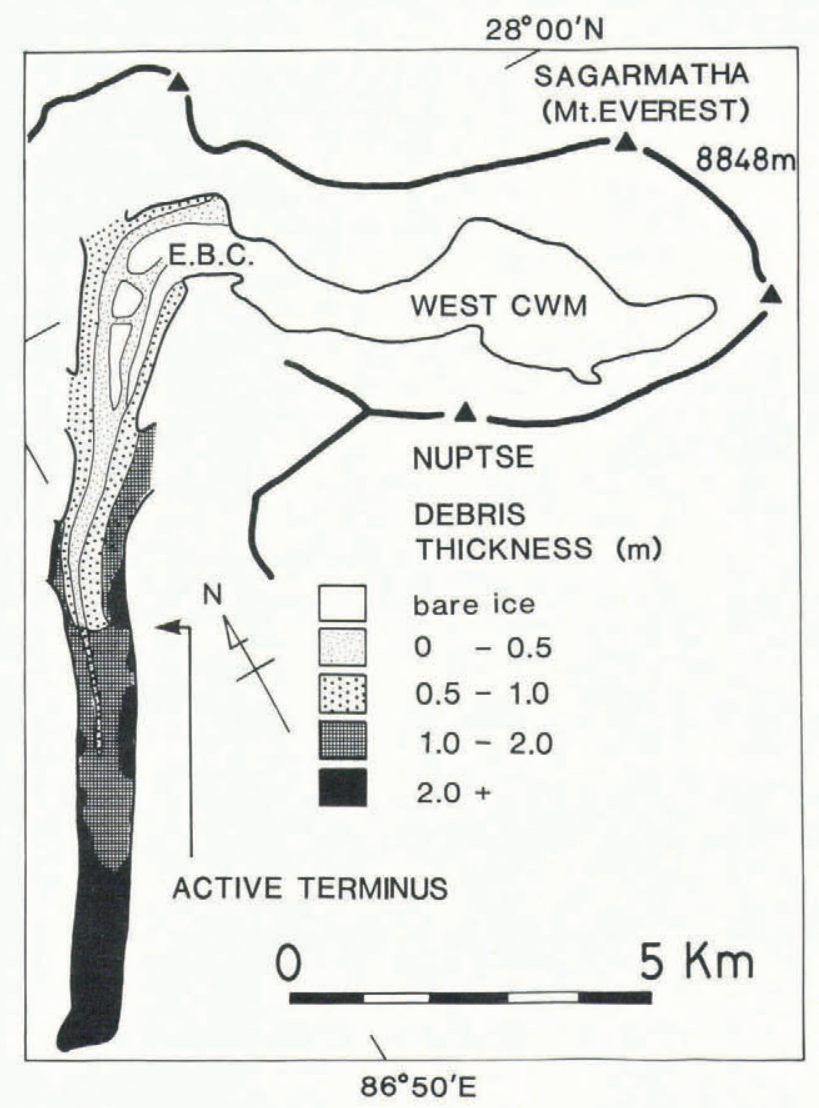

Fig.1. Map of thickness of debris in the ablation area of the Khumbu Glacier. The location of the active terminus was estimated from the topographic features of the glacier, while Fushimi (1977) considered it differently, from a structural study of the glacier. 
on the surface, at cliffs which were usually found at the edges of supraglacial ponds. Morphological, as well as lithological, observations were helpful in compiling an isopach map (Figure 1) of the thickness of the debris from these data. On the basis of the map, it can be concluded that the thickness of debris increases exponentially downglacier, being thicker near the margin than at the centre of the glacier.

The central zone of thin debris is coincident with schistose-rich, debris zone which has a characteristic dark colour (Fushimi et al., 1980). Thick debris near the margin, on the other hand, consists mainly of granitic rocks. Schistose bedrock is found only around the uppermost accumulation basin of West Cwm (Bordet, 1961). It is considered, therefore, that the schistose rock fragments, incorporated into the glacier ice at the West $\mathrm{Cwm}$, were transported downglacier englacially and deposited on the glacier surface through the melting of ice in the ablation area.

Most of the bedrock in the drainage basin of the glacier is granite, except for the schistose outcrop around West Cwm. The incorporation of granitic debris within the glacier ice, therefore, takes place at lower elevations than for the schistose fragments. Various sources of debris falling directly to the glacier surface (supraglacial process) contribute and many such sources are located around the ablation area. Supraglacial debris of subglacial origin should also not be neglected.

\section{ENGLACIAL PROCESS}

Because the spatial distribution of supraglacial debris is the result of three processes (englacial, supraglacial and subglacial), it is usually difficult to assess the magnitude of the individual contribution by each. As mentioned in the previous section, however, supraglacial debris of schistose fragments is considered to originate only from a limited area near the uppermost part of the accumulation basin; hence it must have formed primarily by the englacial process.

The distribution of the mass of schistose debris, $m_{s}$ over the ablation area can be given by the following equation

$$
\mathrm{m}_{\mathrm{s}}=\mathrm{h} \rho w_{\mathrm{s}}
$$

where $\mathrm{h}$ is the thickness of debris given by Figure $1, \rho$ is the nominal density of the supraglacial debris, taken to be $1220 \mathrm{~kg} \mathrm{~m}^{-3}$ (Nakawo, 1979), and $w_{\mathrm{S}}$ is the ratio of the schistose debris to the total debris, which was determined by Fushimi et al. (1980).

The following variables are also introduced here: $\mathrm{x}$ is the distance along the glacier, measured downglacier; $v$ is the velocity of surface flow; $t$ is time; $c_{s}$ is the concentration of the schistose debris in glacier ice; and $r$ is the rate of ablation. The continuity equation for the mass of schistose debris at the glacier surface is thus given by the following equation:

$$
\frac{\partial m_{s}}{\partial t}+\frac{\partial}{\partial x} \quad\left(m_{S} v\right)=r c_{s} .
$$

Under steady state conditions, Equation (2) becomes

$$
m_{s} \frac{d v}{d x}+v \frac{d m_{s}}{d x}=r c_{s} .
$$

This is similar to an equation given by Glazyrin (1975), who neglected the first term on the left-hand side, which characterizes the change of $m_{s}$ attributed to a shrinkage of the surface area caused by the velocity gradient. The flow velocity in Khumbu Glacier, however, decreases very rapidly toward the active terminus, which is located approximately $6 \mathrm{~km}$ upglacier from the apparent terminus. The first term of Equation (3) therefore, cannot be neglected.
Equation (3) can be applied at the central zone of the glacier, where schistose debris predominates. Taking the data $v$ and $r$ from the work of Kodama and Mae (1976) and Inoue and Yoshida (1980), respectively, the concentration of schistose debris, $\mathrm{c}_{\mathrm{s}}$, was estimated. The value obtained was almost constant, at approximately $0.1 \mathrm{~kg} \mathrm{~m}^{-3}$ for the area upglacier from the active terminus. In the area between the active and apparent termini, on the other hand, the calculation resulted in negative values for $c_{s}$. This indicates that the glacier is not stationary in the area in question, that the first term in the left hand side of Equation (2) cannot be neglected, and that the observed flow velocities (Kodama and Mae, 1976) do not represent steady-state velocities.

From the value of $\mathrm{c}_{\mathrm{s}}$ obtained on the active part of the glacier, the annual denudation, $d$, of the schistose bedrock surrounding the West Cwm may be estimated by the following equation:

$$
\frac{\mathrm{c}_{\mathrm{s}}}{\delta_{\mathrm{s}}}=\frac{\mathrm{d}}{\mathrm{p}+\mathrm{d}} \approx \frac{\mathrm{d}}{\mathrm{p}}
$$

where $\delta_{s}$ is the specific gravity of the schistose rock $\left(2500 \mathrm{~kg} \mathrm{~m}^{-3}\right)$. and $\mathrm{p}$ is the annual precipitation in the accumulation basin $\left(540 \mathrm{~mm} \mathrm{a}^{-1}\right)$, which was observed at Lhajung in 1973 (Inoue, 1977). The value of $0.02 \mathrm{~mm} \mathrm{a}^{-1}$ was thus obtained for d.

For granitic debris, it is difficult to assess the contribution from the englacial debris, since the other two processes would have taken place at the same time. The incorporation of granite rock fragments into the glacier ice, however, would generally be at a rate in the same order of magnitude as that for the schistose rocks, although the average concentration of the granitic debris can be larger than that for schistose, since the incorporation of the granitic debris could occur at the ice fall as well. The debris concentration, as a whole, would perhaps be of the order of $0.1 \mathrm{~kg} \mathrm{~m}^{-3}$. From this figure, the production trate of supraglacial debris by the englacial process is on the order of $10^{6} \mathrm{~kg} \mathrm{a}^{-1}$.

\section{SUPRAGLACIAL PROCESS}

Three supraglacial processes can be considered in the formation of the supraglacial debris on the glacier. They are as follows: 1) rock fall, 2) debris avalanche, and 3) failure of lateral moraines. Observations during the 1978 monsoon season showed that the increase in mass of the supraglacial debris by the former two processes is less important than that by the third, which is considered the major supraglacial process.

The glacier surface is generally lower than the crests of the lateral side moraines. The unconformity is presumably caused by the lowering of the glacier surface after the last expansion, when the surface of the glacier would have been equal to or higher than the crests of the lateral moraines. The relative height difference gradually increases downglacier, reaching a maximum value of about $60 \mathrm{~m}$ at a distance of about $6 \mathrm{~km}$ upglacier from the apparent terminus (Watanabe et al., 1986), where the active terminus is probably located. As the glacier surface has been lowered, some of the debris on the inner slope of the lateral moraine, which has become relatively higher, would have slid on to the glacier surface. The amount of the supraglacial debris formed through the failure of the lateral moraine was estimated with the following assumptions.

1) The failure took place after the glacier surface became lower than the crests of the glacier surface. In other words, no debris was supplied at locations where the surface of the glacier is equal to the crests of the moraines in height.

2) The retreat of the interior slope of the moraine is a "parallel retreat", because the debris which slumped on to the glacier would have been carried away by the glacier flow.

The calculation, then, resulted in that about $5 \times 10^{9} \mathrm{~kg}$ of supraglacial debris was contributed to the glacier by slope failure of the lateral moraines after the last expansion of the glacier. 


\section{SUBGLACIAL PROCESS}

It was observed, in cavities formed as englacial water conduits, that debris of subglacial origin is incorporated into the glacier (Yoshida, in preparation). It is difficult, however, to evaluate quantitatively the relative importance of the subglacial process. The denudation rate at various glacier beds has been reported to be in a wide range of 0.1 to $5 \mathrm{~mm} \mathrm{a}^{-1}$ (e.g. Østrem, 1975; Boulton, 1979; Hallet, 1981; Larsen and Mangerud, 1981; Saunders and Young, 1983). When the abrasion rate is multiplied by the ablation area of the Khumbu Glacier, the rate of debris production is $10^{6}$ to $10^{8} \mathrm{~kg} \mathrm{a}^{-1}$, which can be regarded as the contribution of the subglacial process to the formation of supraglacial debris.

From Figure 1, the total mass of the supraglacial debris was estimated to be about $10^{10} \mathrm{~kg}$ on the Khumbu Glacier. For distributing this amount the required time period has been calculated, based upon the production rate of debris mass by the englacial and subglacial processes and the mass of debris attributed to the supraglacial process. The calculation resulted in about 100 years when a large numerical figure is used for the abrasion rate and several hundred years with a small abrasion rate. It is concluded, therefore, that the supraglacial debris has formed for period of the order of hundreds of years, since the last advance of the glacier.

\section{ACKNOWLEDGEMENTS}

The paper has been improved significantly by valuable comments given by $\mathrm{Dr}$ G.Østrem, Dr R.Williams and two anonymous reviewers, to whom the authors are indebted.

\section{REFERENCES}

Bordet P 1961 Recherches géologiques dans l'Himalaya du Nepal, région du Makalu. Paris, Centre National de la Recherche Scientifique

Boulton G S 1979 Process of glacier erosion on different substrata. Journal of Glaciology 23(89): 15-38

Fushimi H 1977 Structural studies of glaciers in the Khumbu region. Seppyo. Journal of the Japanese Society of Snow and Ice, Special Issue 39: 30-39

Fushimi H 1978 Glaciations in the Khumbu Himal (2). Seppyo. Journal of the Japanese Society of Snow and Ice, Special Issue 40: 71-77

Fushimi H, Yoshida M, Watanabe O, Upadhyay B P 1980 Distributions and grain sizes of supraglacial debris in the Khumbu glacier, Khumbu region, east Nepal. Seppyo. Journal of the Japanese Society of Snow and Ice, Special Issue 41: $18-25$

Glaciological expedition of Nepal 1980 Glaciological data on the Khumbu glacier (in 1978). Seppyo. Journal of the Japanese Society of Snow and Ice, Special Issue 41: 107-110

Glazyrin G E 1975 The formation of ablation moraines as a function of the climatological environment. International Association of Hydrological Sciences Publication 104 (General Assembly of Moscow 1971-Snow and Ice): 106-110

Hallet B 1981 Glacial abrasion and sliding: their dependence on the debris concentration in basal ice. Annals of Glaciology 2: 23-28

Inoue J 1977 Mass budget of Khumbu glacier. Seppyo. Journal of the Japanese Society of Snow and Ice, Special Issue 39: 15-19

Inoue J, Yoshida M 1980 Ablation and heat exhange over the Khumbu glacier. Seppyo. Journal of the Japanese Society of Snow and Ice. Special Issue 41: 26-33

Iwata S, Watanabe O, Fushimi H 1980 Surface morphology in the ablation area of the Khumbu glacier. Seppyo. Journal of the Japanese Society of Snow and Ice, Special Issue 41: 9-17

Kodama H, Mae S 1976 The flow of glaciers in the Khumbu region. Seppyo. Journal of the Japanese Society of Snow and Ice, Special Issue 38: 31-36

Larsen E, Mangerud J 1981 Erosion rate of a Younger Dryas cirque glacier at Krakenes, western Norway. Annals of Glaciology 2: 153-158
Nakawo M 1979 Supraglacial debris of $G_{2}$ glacier in Hidden Valley, Mukut Himal, Nepal. Journal of Glaciology 22(87): 273-283

Østrem G 1975 Sediment transport in glacial meltwater streams. In Jopling A V, McDonald B C (eds) Glaciofluvial and glaciolacustrine sedimentation. Tulsa, OK, Society of Economists, Paleontologists and Mineralogists: 101-122 (Special Publication 23)

Saunders I, Young A 1983 Rates of surface processes on slopes, slope retreat and denudation. Earth Surface Processes and Land forms 8: 473-501

Watanabe $\mathrm{O}$ and 7 others 1980 Outline of debris cover project in Khumbu glacier. Seppyo. Journal of the Japanese Society of Snow and Ice. Special Issue 41: 5-8

Watanabe O, Iwata S, Fushimi H 1986 Topographic characteristics on the ablation area of the Khumbu glacier, Nepal Himalaya. Annals of Glaciology 8: 177-180 